Article

\title{
Income Diversification: A Strategy for Rural Region Risk Management
}

\author{
Jinhong Wan ${ }^{1,2, *}$, Ruoxi $\mathrm{Li}^{2}$, Wenxin Wang ${ }^{3}$, Zhongmei Liu ${ }^{1,4}$ and Bizhen Chen ${ }^{5}$ \\ 1 School of Geography, Beijing Normal University, Beijing 100875, China; 201531170013@bnu.edu.cn \\ 2 China Institute of Water Resources and Hydropower Research, Beijing 100038, China; liruoxi@iwhr.com \\ 3 Chongqing Water Resources and Electric Engineering College, Chongqing 402160, China; \\ wenxin840@163.com \\ 4 School of architecture, Linyi University, Linyi 276000, China \\ 5 College of Marxism, Capital Normal University, Beijing 100048, China; bizhen@yeah.net \\ * Correspondence: wanjh@iwhr.com; Tel.: +86-10-6878-6974; Fax: +86-10-6853-6927
}

Academic Editor: Marc A. Rosen

Received: 23 July 2016; Accepted: 8 October 2016; Published: 24 October 2016

\begin{abstract}
Recent literature shows that income diversification is an important strategy for rural households to manage drought risk in arid and semiarid regions. This article examines whether income diversification can help rural households to overcome the adverse impact of drought in Northern China. Based on field interview data from 291 rural households in 13 townships of Northern China, we found that rural households tend to have a more diversified portfolio of income; the spatial location of rural households determines the type and number of income sources, the degree of income diversification, and the income combinations, especially under the context of frequent drought strikes. These results indicate that income diversification could help rural households to reduce the adverse impact of drought, enhance their resistance and resilience to drought, and make their livelihood system more stable. Income diversification not only is a useful strategy in terms of managing disaster risk and improving social welfare, but also may offer a new perspective for the research of vulnerability, resilience, and adaptive ability of rural social-ecosystem.
\end{abstract}

Keywords: income diversification; livelihood; drought; rural household; China

\section{Introduction}

China experiences frequent, spatially extensive, and long lasting droughts that cause the most severe losses to the agricultural economy. In particular, under the context of global warming, the frequency and intensity of droughts have increased [1], which have the potential to become disasters in the absence of a proper mitigation and adaption system. It should be noted that drought, especially extreme drought, is becoming a significant constraint on economic and social development of China. According to national statistics, drought-induced losses take up $42.55 \%$ of disaster losses in China since 1950s [2].

As Wilhite pointed out, the beginning of drought is difficult to detect because it happens very slowly [3]. Partial and short-term drought can have a great influence on local agricultural production, especially during the crop growth period. The rain-fed farming areas such as the county of Xinghe, located in the arid and semiarid regions of Inner Mongolia in China, is one of the most vulnerable areas where drought has become a main constraint on crop production and the local economy. The livelihood of the majority of the Xinghe people depends largely on rain-fed agriculture. Therefore, how to reduce the adverse impact of drought and improve households' livelihood and welfare are important issues for local administrators. 
In developing countries such as China, farm households allocate part of their labor to activities outside of crop planting, such as livestock breeding and wageworker. This allocation of labor constitutes income diversification. A previous study by Barrett et al. suggests that income diversification is a key method of ex ante risk management or ex post coping with weather shocks, such as drought [4]. Studies, including those of Meert et al. [5], Niehof [6], Ellis [7], Watete et al. [8], and Guvele [9] on rural income diversification, suggest that diversification is a key method of reducing reduce vulnerability to weather risk. Therefore, income diversification is a crucial livelihood strategy for the rural region of Xinghe. The main focus of this paper is to examine the role of income diversification, as a risk management strategy, learning from the adverse impact of drought and employing by rural households.

This paper is organized as follows. Section 2 presents a brief review of the key literature on the role of income diversification in reducing vulnerability to drought in arid and semiarid regions. Section 3 describes the studied region, data, and income diversification indices. Section 4 focuses on farmers' income generation activities and farm household income structures of the rural region of Xinghe, which answers the question of why local farm households need to diversify their income sources, analyzes the spatial difference of income diversification by income diversification indices (IDIs) on town and region scales, and rethinks income diversification from a drought management perspective, i.e., whether households with more diversified income sources are able to better withstand the shocks originating from droughts. Section 5 concludes the paper.

\section{Income Diversification as a Risk Management Strategy}

In the real world, few people collect all their income from one source, hold all their wealth in a single form of asset, or use their assets in one activity. Thus, we can say diversification is the norm. Diversification is defined as the process by which rural households construct increasingly diverse livelihood portfolios, making use of increasingly diverse combinations of resources and assets in order to meet their basic needs, improve their living standards or welfare, and manage risk [6]. As Barrett et al. noted, income diversification is widely understood as a form of self-insurance, and it does not seem to be a transient phenomenon or one just associated with survival [4]. It might be associated with success in achieving livelihood security under improving economic conditions as well as with livelihood distress, such as a lack of funds to restore agricultural production in deteriorating conditions [7].

Income diversification refers to the increase in income sources or the balance share among the different sources. As Ellis concludes, under the context of environment uncertainty, most rural households avoid an extended period of dependence on only one or two sources of income [10]. Income diversification is an increasingly important means for rural household living in arid and semiarid areas to managing environment risk. A rural household with multiple income sources will experience less variability in total income than specialized households. Households who have a greater diversity of income sources have a comparative advantage over those with lower diversity. An improving income diversification level causes a variation in both the number of earning activities and the distribution across volumes from each components. Rural households use income diversification for pre-risk management or to cope with weather shocks that have occurred or will occur. Ellis $[7,10]$, Francis [11], Slater [12], and Démurger et al. [13] pointed out that building income diversification was the most important livelihood strategy for rural households to bring more kinds of incomes sources by expanding economic activities (whether it was related to agriculture only, or agriculture and other forms of off-farm income), so as to improve the living condition or to enhance the ability to survive in the harsh environment. In a study that examines the relationship between income diversification and household welfare in Zimbabwe, Ersado found that households living in rural areas with highly variable rainfall were more likely to have a large number of income sources, which was consistent with the idea of income diversity serving as a risk management strategy [14]. Watete et al. pointed out that improved education levels and better access to water are important factors in encouraging adoption of non-farm-based income-generating activities [8]. Guvele also pointed out that households, under the 
drought condition, could more quickly recover from the drought by increasing their sources of income and realized that diversifying income sources was an effective risk transfer strategy [9]. In a study of households' recovery from drought in South Africa, Berzborn pointed out that farmers would find a variety of opportunities in daily life to increase their income and material reserves under the influence of perennial drought [15].

The existing empirical studies on income diversification have several limitations. Most works focus on counting the number of income sources and pay less attention to the share of each source, which may be more important than the former. There is little work comparing the spatial difference of income diversification. Finally, many studies focus on Africa; little focus on China [16]. Thus, this study attempts to extend the empirics on income diversification to fill these gaps.

\section{Data and Methods}

\subsection{Study Area}

Xinghe, with an area of more than $3518 \mathrm{~km}^{2}$, is located in the typical agro-pastoral transitional zone in the southeast of Ulaan Chab City, Inner Mongolia Plateau of Northern China (Figure 1). Based on National Statistics of Land and Resources in 2000, hilly regions account for $36.5 \%$, plain areas account for $38.2 \%$, and mountain areas account for $25.3 \%$ of the total area of Xinghe [17]. The annual precipitation is about $409 \mathrm{~mm}$, while the annual evaporation is above $2037 \mathrm{~mm}$. Therefore, Xinghe is a typical drought-prone area, especially in spring when most crops are cultivated and grown.

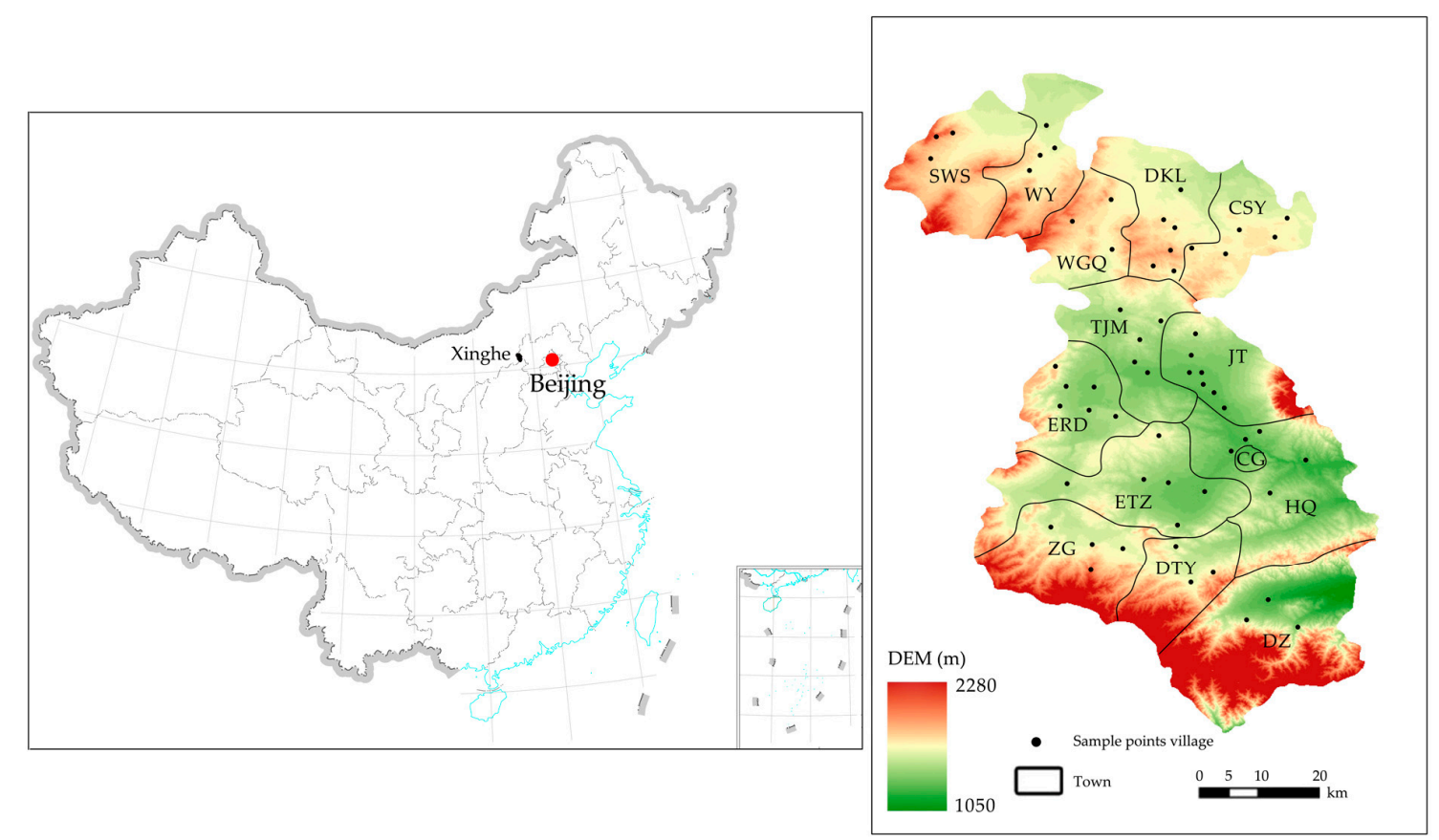

Figure 1. The location of Xinghe in China and the distribution of field observation in 14 towns. DEM is an abbreviation of digital elevation model. Land elevation ranges from 1050 to $2280 \mathrm{~m}$ in Xinghe.

Xinghe has over 14 townships that run 161 administrative villages with a population of more than 314,000 in 2014 . In terms of land use, $26.5 \%$ of the land in the county is used for dry farming, $32.2 \%$ for cattle herding, $33.1 \%$ for forestland, and only $4.6 \%$ for irrigated farming.

\subsection{Data Collection}

Xinghe is a typical agro-pastoral transitional zone, and the income of local rural households, either from agricultural product or livestock, is dependent on weather conditions, the location of the 
household, and family demographic characteristics. If a rural household is located at the plain and has a large area of farming land, especially irrigated land, its agricultural income will be higher than those located in the mountain or hilly areas. If a household is located in a hilly area, they can obtain a good income from livestock farming. In Xinghe, the majority of rural households are smallholders with an average agricultural landholding size of 2.5 ha. The immediate concern is how to improve crop yield, income, and food security, and reduce the forthcoming challenges of livelihood. In order to have a comprehensive understanding of the rural households' economic status in Xinghe, the questionnaire focuses on the following aspects:

A. social characteristics: members, age structure, gender, education level, personal network (mates, friends, etc.), family network, and other related information;

B. economic characteristics: household economic level, total income and expenditure, agricultural income sources, non-agricultural income sources, and other related information;

C. agricultural production characteristics: agricultural production equipment, planting structure, agricultural production strategies under different conditions, and other related information.

With the permission of the local authorities, a dedicated field observation and a questionnaire survey were carried out in Xinghe. The samples distribution of field observation and questionnaire survey are shown in Table 1 and Figure 1. The field observation sites cover 13 townships (the Chengguan (CG) town is not included).

Table 1. Samples distribution of field observation and questionnaire survey.

\begin{tabular}{cccc}
\hline Landform Types & Survey Towns & Number of Sample Villages & $\begin{array}{c}\text { Number of Sample } \\
\text { Rural Households }\end{array}$ \\
\hline \multirow{5}{*}{ North hilly area } & Saiwusu (SWS) & 3 & 14 \\
& Wuyi (WY) & 4 & 19 \\
& Wuguquan (WGQ) & 3 & 14 \\
& Dakulian (DKL) & 6 & 20 \\
Mid plains area & Caosiyao (CSY) & 5 & 21 \\
& Taijimiao (TJM) & 5 & 27 \\
& Tuanjie (TJ) & 7 & 34 \\
South mountain area & Eerdong (ERD) & 6 & 27 \\
& Ertaizi (ETZ) & 6 & 25 \\
& Haoqian (HQ) & 5 & 21 \\
& Zhanggao (ZG) & 4 & 37 \\
& Datongyao (DTY) & 3 & 14 \\
& Dianzi (DZ) & 3 & 18 \\
\hline
\end{tabular}

During the process of the questionnaire survey, we ask the participants' questions on a designed questionnaire (see Appendix A) based on the above considerations. In the end, we obtained 291 completed questionnaires from 291 rural households in 60 administrative villages (in Table 1 and Figure 1).

\subsection{Income Diversification Indices (IDIs)}

In this study, income diversification refers to the increase in income sources and the balance share among sources. Therefore, this paper defined income diversification indices (IDIs) as taking into account both the number of sources and the balance share among them. The IDIs were composed of the income diversity index $\left(I_{d i v}\right)$ and income dependence index [16,18].

The income diversity index $\left(I_{d i v}\right)$ is derived from the Shannon-Wiener index, which is usually used to assess the structural stability of species. The income diversity index is designed to reflect structural stability and more or less rural household income sources; in other words, a higher $I_{d i v}$ value means that the reduction in agricultural income caused by drought does not cause more financial hardship to the households. 
The income dependence index $\left(I_{d e p}\right)$ is designed to analyze whether households have a high dependence on a particular source of income. Higher values of the dependence index of income means that a specific natural hazard may cause risk for rural households and that the rural household needs to pursue a new source of income which is less sensitive to the hazard.

Income diversity index is:

$$
I_{\text {div }}=-\sum_{i=1}^{s} P_{i} \log P_{i}
$$

Income dependence index is:

$$
I_{\text {dep }}=\sum_{i=1}^{s}\left[\frac{N_{i}\left(N_{i}-1\right)}{N(N-1)}\right]
$$

In Equation (1), $s$ denotes the number of income sources; $P_{i}$, the probability of 1 RMB (extracted from the total income) belonging the source $i$.

In Equation (2), $s$ denotes the number of income sources; $N$, the total income; $N_{i}$, the total income from source $i$ and $N_{1}+N_{2}+N_{3}+\ldots+N_{s}=N ; N_{i} / N$, the probability of 1 RMB (extracted from the total income) belonging to source $i ;\left(N_{i}-1\right) /(N-1)$, the probability of 1 RMB (extracted from total income after extracted $1 \mathrm{RMB})$ belonging to source $i$.

\section{Results and Discussion}

\subsection{Farm Household Income Generation Activities}

In this sub-section, the composition of household income is studied. To identify main income generating activities, we classify rural households' income (Table 2) according to which sources they derive income from-farm or non-farm activities based on field observation in Xinghe. The main farm incomes include crop income $(\mathrm{C})$, potato income $(\mathrm{P})$, vegetable income $(\mathrm{V})$, and livestock income $(\mathrm{L})$; non-farm incomes including non-farm wage income $(\mathrm{N})$ and state grants $(\mathrm{S})$.

Table 2. Household income composition of Xinghe.

\begin{tabular}{ccc}
\hline Category & Types & Number of Samples \\
\hline \multirow{3}{*}{ Farm income } & Crop income & 195 \\
& Potato income & 111 \\
& Vegetable income & 36 \\
\multirow{2}{*}{ Off-farm income } & Livestock income & 151 \\
& Non-farm wage income & 155 \\
& State grants & 185 \\
\hline
\end{tabular}

Crop income is the most basic farm income. Crop production provides a basic food source, and surplus crop can be exchanged for cash to improve living conditions. According to the interviews, the main crops in Xinghe are spring wheat, naked oat, benne, millet, and corn. The growing season of these crops is from May to September, but dry weather in this period often leads to low yield; for instance, the yield of benne is $300 \mathrm{~kg} / \mathrm{ha}$ with low rainfall, while the yield reaches $700 \mathrm{~kg} / \mathrm{ha}$ with normal rainfall. However, each family has about 2.5 ha of farmland on average. In other words, the advantage of the land size can compensate for the lower yield. The survey shows that crop sale could bring in about RMB 3000 (about 500 US dollars).

Potato income is another important source of farm income. Thanks to the soil and climate conditions in Xinghe, potato has excellent yield (about 12,000 kg/ha). Farmers could sell surplus potatoes for cash. In local markets, the average price of potato is RMB 1 per kilo, and most households could sell 3000-4000 kg during the harvest season and next spring. 
Vegetable income is also an important source of income for mid plain areas. According to field observations in TJ, the income from cabbage and sugar beet could account for more than $30 \%$ of household income.

Livestock farming, mainly cattle and sheep or goats, is an important farm activity in northern hilly areas and southern mountain areas. According to the surveys in DZ and SWS, where seasonal livestock trade fairs are held each year, a head of cattle can be sold for RMB 4000 in DZ, and a sheep can be sold for RMB 200 in SWS.

Non-farm wage is a significant income source for households with young members. As wage labor, they enjoy stable monthly income of about RMB 2000 or more. Some local respondents said that they or their children could contribute about RMB 3000-4000 every year.

State grants are the least important source of income in Xinghe. In China, the elderly and disabled generally receive state pensions. In 2009, the monthly state pension per person was RMB 100; in 2013, it was RMB 150; now, it is RMB 300. Usually, the elderly often live with their families and contribute their pensions to the household budget. Meanwhile, from 1999 to 2002, China had returned a total of 7.6 million hectares of land to forests or grassland. Since 2002, the Xinghe government has paid RMB 1000 per hectare to farmers who returned their own farmland to forests or grassland each year. These state grants represent a significant and stable income in rural area, particularly when it is compared with the financial circumstances of many non-pensioners.

\subsection{Determinants of Income Diversity}

The interview data indicates that rural households derive income from farming mainly, which on average accounts for a $60 \%$ share of total household income, $66 \%$ in north hilly areas, $74 \%$ in mid plains areas, $52 \%$ in south mountain areas. Table 2 shows that crop production is the most important source of income; more than $67 \%$ of farm households from the surveyed sample derive money from crops sale; subsidies for returning land to forests and grassland make up for nearly $64 \%$ of state grants a household receives; more than $53 \%$ of families have adult members working as wage laborers in urban areas; about $52 \%$ of households gain money from livestock fairs; about $38 \%$ of households derive income from potato production; and more than $12 \%$ of households earn money from vegetable sales.

Based on the income classification above, we describe statistical characteristics of a number of income sources. Table 3 shows that the education level of the household head is significantly and positively related to the number of income sources, as studies $[19,20]$ have explained that high education levels open the window to different economic activities. Good education means engaging in more diverse activities and yields greater chances of earning more money [8]. The results also reveal that rural households with a small proportion of children and elderly people tend to diversify income sources, since a greater proportion of children of household members means that fewer family members are able to engage in agricultural production or migrant workers.

Table 3. Rural household statistical characteristics of the number of income sources.

\begin{tabular}{cccc}
\hline Variable & Coefficient & Std Error & $t$ \\
\hline Age of household head & -0.007 & 0.011 & -0.482 \\
Education of household head (years) & 0.024 & 0.008 & $2.985^{* *}$ \\
Household size & 0.134 & 0.017 & $7.528^{* *}$ \\
Proportion children of household & -0.008 & 0.002 & $-3.093^{* *}$ \\
Proportion older of household & -0.006 & 0.006 & $-2.072^{*}$ \\
Farm size & 0.273 & 0.062 & $1.986^{*}$ \\
Share of land irrigated & -0.459 & 0.118 & $-3.022^{* *}$ \\
\hline
\end{tabular}

Note: $N=291$. The mean number of income sources is 2.858 , the standard deviation is 0.639 , the min is 1 , and the max is $6 .{ }^{* *}$ The significance at the $1 \%$ level; ${ }^{*}$ at the $5 \%$ level.

Based on marginal economic theory, in a farm of a particular size, the marginal product of additional family labor in crop production declines as the household size increases, which makes 
it likely that alternative sources of income would be attractive. This is why many surplus laborers engage in non-farm activities. The more working-age adults there are, the more likely it is that that household will have a range of skills that allows income diversity at the household level. In addition, the size of the farmland is also significantly and positively related to the number of income sources. Partly, more land means that those households have greater opportunities to diversify crop mixes and increase income from different crops. However, if a household has a large share of irrigated land that needs a large number of working-age adults to cultivate, it will be prone to fewer income sources from non-farm activities during the growing season.

\subsection{Spatial Difference of Income Diversification at The Town Scale}

In this sub-section, we investigate the regional spatial differences of the rural households engaging in different income generating activities. The field survey show that $27.2 \%$ of households have two sources of income, $33.3 \%$ of households have three sources of income, $19.6 \%$ of households have four sources of income, and $8.6 \%$ of households have five or more sources of income. The most common income combinations are CP, PLS, CPN, and CPNS in northern hilly areas; CV, CN, and CNS in mid plain areas; and CN and CLSN in southern mountain areas.

With Equations (1) and (2), we calculated the $I_{d i v}$ and $I_{d e p}$ at the township scale of Xinghe (Table 4). Like two sides of a coin, the trend of the value of $I_{\text {dep }}$ shows a direction opposite to that of $I_{\text {div }}$. A higher value of $I_{d i v}$ corresponds with a lower value of the $I_{d e p}$. In other words, a high value of $I_{d i v}$ and low value of $I_{d e p}$ means that a household can derive income from one source to compensate the loss of another caused by weather shock, crops or livestock market failure, or poor opportunities working as wage laborers.

Table 4. Household income diversification indices and average number of income sources.

\begin{tabular}{ccccc}
\hline Landform Types & Surveyed Towns & $\boldsymbol{I}_{\text {div }}$ & $\boldsymbol{I}_{\text {dep }}$ & $\begin{array}{c}\text { Average Number } \\
\text { of Income Sources }\end{array}$ \\
\hline \multirow{5}{*}{ North hilly area } & Saiwusu (SWS) & 0.572 & 0.643 & 2.286 \\
& Wuyi (WY) & 0.685 & 0.563 & 2.421 \\
& Wuguquan (WGQ) & 0.605 & 0.630 & 2.429 \\
& Dakulian (DKL) & 0.664 & 0.602 & 2.550 \\
& Caosiyao (CSY) & 0.507 & 0.685 & 1.952 \\
\hline \multirow{3}{*}{ Mid plains area } & Taijimiao (TJM) & 1.172 & 0.366 & 4.037 \\
& Tuanjie (TJ) & 0.834 & 0.513 & 2.912 \\
& Eerdong (ERD) & 0.826 & 0.510 & 2.815 \\
\hline \multirow{5}{*}{ South mountain area } & Ertaizi (ETZ) & 0.564 & 0.662 & 2.286 \\
& Haoqian (HQ) & 0.725 & 0.564 & 2.640 \\
& Zhanggao (ZG) & 0.931 & 0.475 & 3.351 \\
& Datongyao (DTY) & 1.189 & 0.361 & 4.000 \\
& Dianzi (DZ) & 0.721 & 0.584 & 2.833 \\
\hline
\end{tabular}

Table 4 shows the value of $I_{d i v}$ and $I_{d e p}$ at the township scale of Xinghe. The results show that DTY in a southern mountain area has the highest income diversity, with an $I_{d i v}$ value of 1.189 and an $I_{d e p}$ value of 0.361 ; CSY in a northern hilly area has the lowest income diversity, with an $I_{\text {div }}$ value of 0.507 , and an $I_{d e p}$ value of 0.685 . Sorted according to income diversity at the township scale, the descending order is DTY, TJM, ZG, TJ, ERD, HQ, DZ, WY, DKL, WGQ, SWS, ETZ, and CSY.

Table 4 also indicates that location plays an important role in the spatial differences of income diversity among those townships. Results show that mid plains areas have the highest income diversity, with an $I_{d i v}$ value of 0.935 and $I_{d e p}$ value of 0.467 ; southern mountain areas are lower than mid plain area, with an $I_{d i v}$ value of 0.812 and $I_{d e p}$ value of 0.535 ; northern hilly areas have the lowest income diversity, with an $I_{d i v}$ value of 0.607 and $I_{d e p}$ value of 0.624 . This indicates that the households in the central and southern areas have a more stable livelihood compared with those in the northern 
areas, and have more opportunities to compensate for the agricultural loss caused by drought with non-agricultural income. In other words, residents in the central and southern areas are more resilient than those in the northern areas of the county. According to the survey, the average number of income sources for households is 2.3 in northern hilly areas, 3.2 in mid plains areas, and 3.0 in southern mountain areas, respectively.

Furthermore, environmental attributes, such as precipitation, groundwater resources, and surface slopes, vary at different locations and determine the agricultural production activity types and crop types. In arid and semiarid regions, there is a significant difference in crop yield between irrigated land and rain-fed land. For instance, in the northern hilly area of Xinghe where there are large areas of rain-fed farmland, when the dry weather occurs in the growing season, it often leads to serious loss of agricultural production. Thus, it is difficult for towns like SWS, WY, WGQ, DKL, and CSY in the northern areas to obtain the same agricultural income as towns such as TMG and TJ, which have large areas of irrigated land in the mid-plain areas. According to field interviews, peasants in TJ can plant wheat, corn, potato, and some kinds of vegetables, while the options of peasants in SWS are limited to spring wheat and potato. Thus, the annual average farm income is above RMB 5000 in the central areas, contrasted to RMB 1500 in the northern hilly areas.

\subsection{Why Rural Households Diversify Their Income Sources?}

Economic reforms launched in the early 1980s have led to important changes in agricultural production activities in rural China. On the one hand, the Household Contract Responsibility System makes it possible for rural households to decide on their farm or non-farm activities by themselves. On the other hand, the emergence of market mechanisms encourages profit-oriented activities. Economic reforms have brought incentives and opportunities for rural households of large sizes to diversify both farm and non-farm activities. Thus, the interviews with household heads show that large households with few children and elderly members are also more likely to have a large share of income from farm or non-farm activities, especially in TMG or TJ in mid plains areas. In other words, it is true that the more working-age adults there are in a household, the higher share the non-farm income takes up.

Weather plays a key role in the household farm and non-farm activity diversification process. In Xinghe, drought is a major "push" factor that encourages rural households to turn to a more diversified portfolio of activities and thus strongly influences rural crop production, income, and welfare. Both farm and non-farm diversification can thus be seen as efficient mechanisms for households to reduce income risks caused by continuous drought. However, within the context of climate change, the uncertainty of weather events may make local rural households more likely to engage in new activities, especially non-farm activities.

Crop insurance is one of the most useful risk management tools for adapting to climate change [21-23]. Since 2007, some large insurance companies (such as PICC) have provided crop insurance. Due to the crop insurance subsidy from the government, China's crop insurance program has made unprecedented progress. However, current crop insurance focuses on flood disaster, not drought. In our field survey, local farmers said that they did not receive any drought crop insurance subsidies. Of course, some farmers in arid regions can receive crop drought insurance today. However, the implementation of drought crop insurance will face many obstacles in the future. The most important point is that drought occurs almost every year in arid and semiarid regions such as Xinghe. Meanwhile, one study [24] has shown that the diversity of income sources significantly and negatively affects farmers' willingness to participate in crop insurance. The field survey shows that, in Xinghe, most rural households believe that increasing the source of income is the best insurance to resisting drought.

Crop diversification is a drought risk management strategy. In Xinghe, the lack of household savings and agricultural insurance means that farmers are unable to smooth out consumption through ex post mechanisms. Therefore, they can allocate household resources to secure a more 
stable income through diversifying farm or non-farm activities. This could be interpreted as drought risk management-a deliberate ex ante strategy towards anticipating possible negative events and counteracting expected failures in various income streams in the future. For instance, based on the water demand for the varieties of different crops in the growing season, local farmers often adopt highly diversified crop planting strategies to reduce weather-related risks $[8,25,26]$, as Makate et al. pointed out that crop diversification is a viable climate-smart agriculture practice that significantly enhances crop productivity and consequently resilience in rural smallholder farming systems [26]. Figure 2 shows that, in order to reduce drought risk, many local rural households in Xinghe divide their land holdings into several plots for different crops, such as spring wheat, naked oats, and potato, since the sensitivity of different crops on the environment is different. It can be concluded that mixed planting leads to diversified income sources for rural households. The seasonal use of labor in rural areas is very important for income diversification. Seasonal laborers working as wage laborers in urban areas are an important source of income for rural households. Non-farm activities could absorb surplus labor, help farm-based households spread risk, offer more remunerative activities to supplement or replace farm income, offer income potential during the agricultural off-season, and provide a means to cope with or survive crop failures caused by droughts. As Table 2 suggests, 155 out of the 291 surveyed rural households have family members working as migrant workers in urban areas.

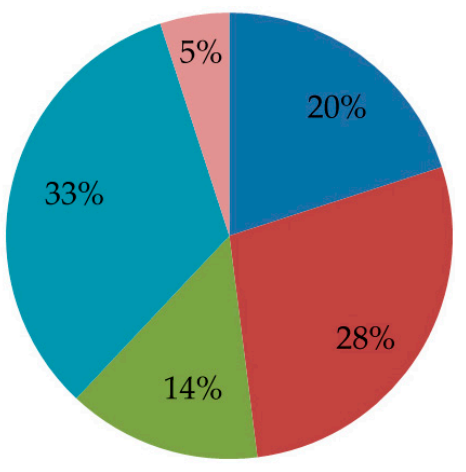

Northern hilly area

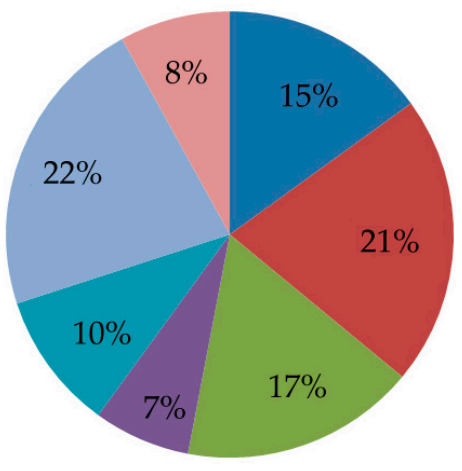

Southern mountain area

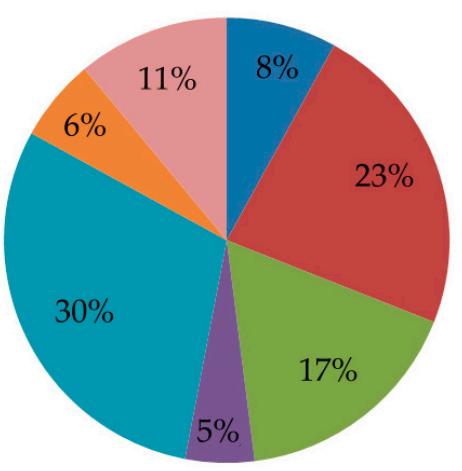

Mid plain area

Spring wheat
Naked oats
Potato
Corn
Benne
Beetroots
Millet
Other

Figure 2. Planting structure of major farm crops in three subregions of Xinghe.

\section{Conclusions and Recommendations}

This study proposes and investigates income diversification as a potential strategy of risk management, and income and welfare improvement for rural households. This paper has examined the income diversification in agricultural and farming regions in China and found that household 
characteristics determine the number of income sources, and the location of a household determines the level of diversification. This result indicates that income diversification is an effective and valuable strategy for local rural households to cope with weather shock since it can reduce the impact of weather disasters, enhance the ability of combating and recovering from drought, make rural households' livelihood system more stable, and provide new ideas for rural disaster management and relief.

The findings of this study can be used to generate or improve policies aimed at reducing weather risk among rural communities. In particular, the evidence that income diversification enhances family economic stability shows that income diversification should be considered as a possible strategy for reversing the livelihood status among rural communities. For instance, rural development should focus on ways to increase land productivity of crop production and the income therefrom. Crop diversification is an important approach to improve farm income. Moreover, local governments should promote non-farm employment through policies and regulation, so as to, for example, improve access to credit for small enterprises.

Acknowledgments: This study is supported by the Special Fund of National Science and Technology China (No. 2014FY130500), National Natural Science Foundation of China (No. 41601569), and China Postdoctoral Science Foundation (No. 2016M591214). The authors are grateful to the editor and two anonymous reviewers who took the time to review and provide guidance on this paper.

Author Contributions: Jinhong Wan conceived and designed the experiments; Jinhong Wan, Ruoxi Li, Wenxin Wang, and Zhongmei Liu performed the experiments; Jinhong Wan, Bizhen Chen and Ruoxi Li analyzed the data; Wenxin Wang contributed reagents/materials/analysis tools; Jinhong Wan, and Ruoxi Li wrote the paper.

Conflicts of Interest: The authors declare no conflict of interest.

\section{Appendix Agricultural Drought Survey Questionnaire}

This questionnaire contains five questions, please answer according to the actual situation of your family.

No.:

Location:

Date:

Respondents:

(1) Household structure

\begin{tabular}{lllllll}
\hline Member Relationship with Respondent & Gender & Age & Education Level & Jobs & Health Status \\
\hline
\end{tabular}

Relationship with Respondent: 1-Grandparents; 2-Parents; 3-Children; 4-Brothers and sisters; 5-Spouse; 6-Friend; Gender: 1-Male; 2-Female; Education level: 1-illiteracy; 2-Primary School; 3-High School; 4-college; Jobs: 1-Farmer; 2-Wage Worker; 3-Rural Retailer; 4-Local government staff; 5-Student; Health status: 1 -good; 2 -illness.

\section{(2) Household storage of grain and food}

\begin{tabular}{lll}
\hline Items & Quantity of Grain And Food Storage (kg) & Annual Consumption of Grain And Food (kg) \\
\hline Millet & & \\
Beetroots & \\
Benne & \\
Corn & \\
Naked oats & \\
Spring wheat & \\
Potato & \\
\hline
\end{tabular}




\section{(3) Household income-expenditure}

(a) Household income

\begin{tabular}{cc}
\hline Income Sources & Annual Income \\
\hline Crop income & \\
Potato income & \\
Vegetable income & \\
Livestock farming income & \\
Non-farm income & \\
State grants & \\
Total income & \\
\hline
\end{tabular}

Annual income: 1-below 1000 RMB, 2-1000-5000 RMB, 3-5000-10,000 RMB, 4-more than 10,000 RMB.

(b) Household expenditure

\begin{tabular}{cc}
\hline Expenditure Items & Annual Expenditure \\
\hline Agricultural input & \\
Investment in animal husbandry & \\
Investment in agricultural product processing industry \\
Daily consumption \\
Total household expenditure
\end{tabular}

\section{(4) Household agricultural production}

(a) Total cultivated land area:__hectares, irrigated land:_hectares

(b) Planting situation fill the table

\begin{tabular}{|c|c|c|c|}
\hline Species & Planting Area (ha) & Yield per Unit Area (kg/ha) & $\begin{array}{l}\text { Drought Resistant Ability } \\
\text { (Best/Middle/Worst) }\end{array}$ \\
\hline $\begin{array}{c}\text { Millet } \\
\text { Beetroots } \\
\text { Benne } \\
\text { Corn } \\
\text { Naked oats } \\
\text { Spring wheat } \\
\text { Potato }\end{array}$ & & & \\
\hline
\end{tabular}

\section{(5) Household livestock breeding}

\begin{tabular}{|c|c|c|}
\hline Species & Quantity & Does It Need to Buy Livestock Feed (Y/N) \\
\hline $\begin{array}{c}\text { pig } \\
\text { sheep } \\
\text { cattle } \\
\text { donkey } \\
\text { Horse } \\
\text { chicken }\end{array}$ & & \\
\hline
\end{tabular}

Thank you for your participation.

\section{References}

1. Leng, G.; Tang, Q.; Rayburg, S. Climate change impacts on meteorological, agricultural and hydrological droughts in China. Glob. Planet Chang. 2015, 126, 23-34. [CrossRef] 
2. Ministry of Water Resources of the People's Republic of China (MWR). Bulletin of Flood and Drought Disaster in China; China Water Power Press: Beijing, China, 2014; pp. 1-2.

3. Wilhite, D.A. Drought. In Encyclopedia of Earth System Science; Academic Press: San Diego, CA, USA, 1992; pp. 81-92.

4. Barrett, C.B.; Reardon, T.; Webb, P. Nonfarm income diversification and household livelihood strategies in rural Africa: concepts, dynamics, and policy implications. Food Policy 2001, 26, 315-331. [CrossRef]

5. Meert, H.; van Huylenbroeck, G.; Vernimmen, T.; Bourgeois, M.; Van Hecke, E. Farm household survival strategies and diversification on marginal farms. J. Rural Stud. 2005, 21, 81-97. [CrossRef]

6. Niehof, A. The significance of diversification for rural livelihood systems. Food Policy 2004, 29, 321-338. [CrossRef]

7. Ellis, F. Household strategies and rural livelihood diversification. J. Dev. Stud. 1998, 35, 1-38. [CrossRef]

8. Watete, P.W.; Makau, W.K.; Njoka, J.T.; AderoMacOpiyo, L. Are there options outside livestock economy? Diversification among households of northern Kenya. Pastoralism 2016, 6, 1-13. [CrossRef]

9. Guvele, C.A. Gains from crop diversification in the Sudan Gezira scheme. Agric. Syst. 2001, 70, 319-333. [CrossRef]

10. Ellis, F. Rural Household and Diversify in Developing Countries; Oxford University Press: Oxford, UK, 2000; pp. 1-15.

11. Francis, E. Making a Living, Changing Livelihoods in Rural Africa; Rout ledge: London, UK, 2000; pp. 1-99.

12. Slater, R. Differentiation and diversification: Changing livelihoods in Qwaqwa, South Africa, 1970-2000. J South. Afr. Stud. 2002, 28, 599-614. [CrossRef]

13. Démurger, S.; Fournier, M.; Yang, W. Rural households' decisions towards income diversification: Evidence from a township in Northern China. China Econ. Rev. 2010, 21, S32-S44. [CrossRef]

14. Ersado, L. Income Diversification in Zimbabwe: Welfare Implications from Urban and Rural Areas; FCND Discussion Paper No. 152; International Food Policy Research Institute: Washington, DC, USA, 2003; pp. 1-50.

15. Berzborn, S. The household economy of pastoralists and wage-laborers in the Richtersveld, South Africa. J. Arid Environ. 2007, 70, 672-685. [CrossRef]

16. Wan, J.H.; Wang, J.A.; Liu, Z.; Jia, H.C.; Gao, L.; Gao, L.L.; Zhang, F. Drought resilience in view of income diversity of peasant household: A case study on Xinghe County, Inner Mongolia. J. Nat. Disasters 2008, 17, 122-126. (In Chinese)

17. Xinghe County. Available online: http://www.xinghe.gov.cn/channel/xinghe/col23268f.html (accessed on 5 September 2016).

18. Zhou, H.J.; Wang, J.A.; Wan, J.H.; Jia, H.C. Resilience to natural hazards: A geographic perspective. Nat Hazards 2010, 53, 21-41. [CrossRef]

19. De Brauw, A.; Rozelle, S. Reconciling the returns to education in off-farm wage employment in rural China. Rev. Dev. Econ. 2008, 12, 57-71. [CrossRef]

20. De Brauw, A.; Huang, J.; Rozelle, S.; Zhang, L.; Zhang, Y. The evolution of China's rural labor market during the reforms. J. Comp. Econ. 2002, 30, 353-529. [CrossRef]

21. Risk Modeling Concepts Relating to the Design and Rating of Agricultural Insurance Contracts. Available online: https: / / ssrn.com/abstract=625269 (accessed on 1 August 2004).

22. Charpentier, A. Insurability of climate risks. Geneva Pap. Risk Insur. Issues Pract. 2008, 33, 91-109. [CrossRef]

23. Jin, J.J.; Wang, W.Y.; Wang, X.M. Adapting agriculture to the drought hazard in rural China: Household strategies and determinants. Nat. Hazards 2016, 82, 1609-1619. [CrossRef]

24. Yang, X.J.; Liu, Y.; Bai, W.; Liu, B.C. Evaluation of the crop insurance management for soybean risk of natural disasters in Jilin Province, China. Nat. Hazards 2015, 76, 587-599. [CrossRef]

25. Ashraf, M.; Routray, J.K.; Saeed, M. Determinants of farmers' choice of coping and adaptation measures to the drought hazard in northwest Balochistan, Pakistan. Nat. Hazards 2014, 73, 1451-1473. [CrossRef]

26. Makate, C.; Wang, R.; Makate, M.; Mango, N. Crop diversification and livelihoods of smallholder farmers in Zimbabwe: Adaptive management for environmental change. Springerplus 2016, 5, 1-18. [CrossRef] [PubMed]

(C) 2016 by the authors; licensee MDPI, Basel, Switzerland. This article is an open access article distributed under the terms and conditions of the Creative Commons Attribution (CC-BY) license (http://creativecommons.org/licenses/by/4.0/). 